\title{
Effect of manure sources and rates on nitrogen replacement value, sesame yield and nutrient content under drip irrigation system
}

\author{
E. M. Abd El Lateef ${ }^{*}$ (D, Asal M. Wali ${ }^{2}$ and M. S. Abd El-Salam
}

\begin{abstract}
Background: This work was conducted to investigate the effect of different manure types (compost, chicken manure and FYM) at 12, 24 and $48 \mathrm{~m}^{3} \mathrm{ha}^{-1}$ with or without reduced $\mathrm{N}$ rate $\left(72 \mathrm{~kg} \mathrm{ha}^{-1}\right)$ compared with $\mathrm{N}$ fertilizer levels: 0,36 , 72 and $108 \mathrm{~kg} \mathrm{ha}^{-1}$ under drip irrigation system. Therefore, field trials were established in the summer seasons of 2018 and 2019 on a private farm, Belbais District, Sharkia Governorate, in a newly reclaimed soil (loomy calcareous). Sesame seed yield, oil content and macro- and micronutrients were determined.

Results: Highly significant effects due to organic sources applied were apparent on seed yield and yield components. Yield response to FYM at the lowest rate compared to the other two sources and rates was evident. Correlation analysis of the various yield characteristics with $\mathrm{N}$ fertilizer application was reported. Fertilizer replacement value in manure sources ranged between 30 and $62 \%$. The chemical analysis of sesame seeds indicated that chemical composition of sesame seed was insensitive to the type of soil amendment.

Conclusion: It could be concluded from this study that the predictable benefits from manure application to sesame will increase farmer confidence in organic fertilizers reducing the reliance up on inorganic fertilizers for crop nutrition and improving the sesame seed nutrient content.
\end{abstract}

Keywords: Sesame, Organic manure, Yield, Oil, Protein, N equivalency, Macro- and micronutrient status

\section{Background}

Sesame (Sesamum indicum L.) is an important oil seed crop grown in tropical and subtropical areas with high nutritive value (Ashri 1989; NCRI 2005). The main important world producers are India, China, Sudan, Myanmar, Ethiopia, Uganda and Nigeria (Wikipedia 2009).

The demand on sesame is increasing for its multiple uses, but there is a wide gap between production and consumption of sesame in Egypt. Sesame cultivation is

\footnotetext{
*Correspondence: profabdellateef@gmail.com

${ }^{1}$ Agricultural Division, Field Crops Research Department, National

Research Centre, 33 El-Behooth St., Giza, Egypt

Full list of author information is available at the end of the article
}

sensitive to unsuitable soil conditions such as low fertility, salinity and poor moisture retention. Due to the shortage of animal manures, it is important to substitute other materials as organic wastes and composts to fulfill the organic matter requirement of these soils (Abd El Lateef et al. 2019a). Soil amendments such as farmyard and chicken manures are handled by many investigators as soil conditioners and fertilizers for increasing growth and yield of many field crops and vegetables (Abd El Lateef et al. 2019b). Organic materials are a major source of organic matter and plant nutrients resulting in improved soil physical and chemical attributes, especially nutrient content (Craswell and Lefroy 2001; Murphy 2015). Application of organic manures to sesame improves its seed 
yield and quality (Mbagwu and Ekwealor 1990; Anyanga and Obong 2001; Bedigian 2003; Morris 2002).

Slow and gradual lasting release of a wide range of nutrient elements to the soil could be achieved by organic matter (Ogbonna and Umar-Shaba 2012; Abd El-Lateef et al. 2019a).

Both macro- and micronutrients integrated with organic amendments like farmyard manures should be saved to sesame (Singh et al. 2018). Abdel Sabour and Abo El Soud (1996) indicated that all compost treatments have beneficial effects to sesame.

Integration of organic and inorganic fertilizer could save better nutrient management in sesame with advantages of maintaining higher productivity and providing stability in crop production, balanced proportion for sustainable production of sesame besides improving soil physical conditions (Teshome 2016; Sahu et al. 2018). Higher seed yield of sesame can be obtained by integrated use of fertilizer along with FYM (Purushottam 2005; Sahu et al. 2017). Haruna and Abimiku (2012) found that application of $2.5 \mathrm{t} \mathrm{ha}^{-1}$ of poultry manure produced the highest value for all the yield attributes measured.

These trials aimed to manage the use of different manure sources and rates, for a new crop for this type of land under drip irrigation. Another objective was to determine nitrogen fertilizer replacement value of different manure sources and to monitor the nutritional status of macro- and micronutrients in sesame seeds.

\section{Methods}

Two field trials were carried out in the summer of 2018 and 2019 seasons on a private farm, $8 \mathrm{~km}$ east of Bilbeis, south of Ismailia Canal, Sharkia Governorate, in a newly reclaimed sandy calcareous soil (EC $6.3 \mathrm{ds} \mathrm{m}^{-1}$ ), $\mathrm{CaCO}_{3}$ (5.6-19\%). The objective of the trials was to manage different soil ameliorating nutrients through manure application types (Compost, chicken manure and FYM) at rate of 12,24 and $48 \mathrm{~m}^{3} \mathrm{~h}^{-1}$ with or without reduced $\mathrm{N}$ rate $\left(72 \mathrm{~kg} \mathrm{ha}^{-1}\right)$ as well as $\mathrm{N}$ fertilizer levels: $0,36,72$ and $108 \mathrm{~kg} \mathrm{ha}^{-1}$ on sesame yield and nitrogen fertilizer equivalency under drip irrigation system. Another objective of this work was to monitor the nutritional status of macro- and micronutrients in sesame seeds. The soil was newly reclaimed desert soil (loomy calcareous), and the physical and chemical analyses of the soil are listed in Table 1. Each experiment included 22 treatments as listed in Tables 6 and 8. The experimental design in the trials was complete randomized block design (CRBD) with four replicates. Manures were delivered to the site, and the chemical analysis of the manures applied is given in Table 2. The experimental soil was plowed twice with fixed-tine harrow and divided to experimental units each of $21 \mathrm{~m}^{2}$ area. Thereafter, the manures were calibrated on a volumetric basis and applied to the assigned plots. Manure application was carried out manually according to common farmyard manure application in the district. In order to ensure homogenous incorporation with the soil surface layer, a rotary cultivator was used. Sesame (Sesamum indicum L.), Mutation 48, was sown on June 25, 2018, and June 15, 2019 seasons, respectively. Sowing was carried out by hand at $15 \mathrm{~cm}$ distance in the wetting area of the drippers line. Irrigation was applied every two-day intervals.

The agronomic practices for sesame followed the normal farmer practice in the district. During seed-bed preparation, the phosphatic fertilizer was applied as calcium superphosphate $\left(15.5 \% \mathrm{P}_{2} \mathrm{O}_{5}\right)$ was applied at $76 \mathrm{~kg}$ $\mathrm{P}_{2} \mathrm{O}_{5} \mathrm{ha}^{-1}$. Nitrogen was applied as ammonium sulfate $(20.6 \% \mathrm{~N})$ in split applications through fertigation, while the potassium was applied as potassium sulfate (48-52\% $\mathrm{K}_{2} \mathrm{O}$ ) at $57 \mathrm{~kg} \mathrm{~K}_{2} \mathrm{O} \mathrm{ha}{ }^{-1}$. Harvesting of the sesame was carried out on 20 and 15 September in first and second seasons, respectively.

\section{Data collected}

Sesame plant height, number of branches and capsules plant $^{-1}$ were determined. All plants from each plot were harvested left in the field until full drying to determine seed yield $\mathrm{ha}^{-1}$, harvest index, seed oil yield $\mathrm{ha}^{-1}$ and seed protein yield $\mathrm{ha}^{-1}$.

\section{Chemical analysis}

Seeds of harvested sesame were analyzed for their contents of nutrients. Chemical analysis was carried out on dried and ground samples. Nitrogen was determined by micro-Kjeldahl according to the AOAC (2005). After wet digestion of the samples, according to Chapman and Pratt (1978), P was determined by spectrophotometry, K was determined by flame photometer (Jackson 1967) and $\mathrm{Fe}, \mathrm{Mn}, \mathrm{Cu}$ and $\mathrm{Zn}$ were determined by atomic absorption spectrophotometry. Other analyses were according to the methods described by Jackson (1967). Seed oil content (\%) was determined by using Soxhlet extraction apparatus using petroleum as a solvent according to AOAC (2005).

Oil yield and seed protein yield ha ${ }^{-1}$ were calculated by multiplying seed yield $\times$ seed oil percentage and seed protein $\%$, respectively.

To define the optimum dressings of manure sources for crop production, a dynamic modeling approach was used to describe yield effects and quantitative numerical descriptions of the relationships between crop yield and the amount of a particular input applied to the soil.

The model used to describe the crop yield takes the numerical form (Cooke 1982) as follows: 


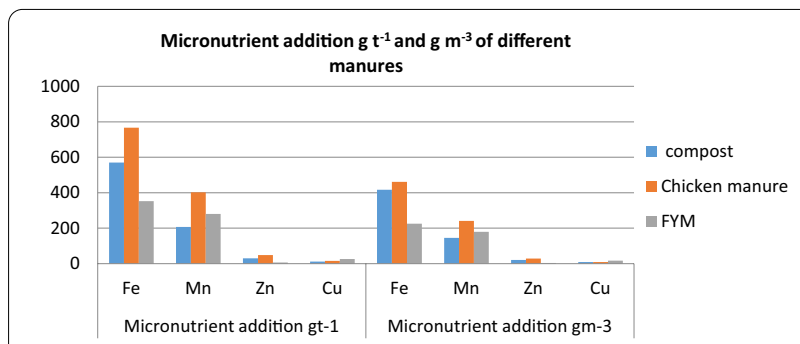

Fig. 1 Micronutrient addition in the different manures applied

Linear model: $y=a+b_{1} x$

where $y$ is the measured yield variable (units: $\mathrm{tha}^{-1}$ or $\mathrm{kg}$ $\left.\mathrm{ha}^{-1}\right) ; b_{1}$ is the regression coefficient representing the linear gradient (or slope) of the incremental yield response to increasing application rate; $x$ (units: $\mathrm{kg} \mathrm{ha}^{-1}, \mathrm{~m}^{3} \mathrm{ha}^{-1}$ ) of the fertilizer or manure; and $a$ is a constant value (intercept) representing the yield obtained without fertilizer or manure. The $\mathrm{N}$ fertilizer equivalency is calculated by dividing the regression coefficient for the manure, on the basis of its rate of total $\mathrm{N}$ application, with the coefficient obtained for the yield response to applied mineral $\mathrm{N}$. The units quantifying the rate of $\mathrm{N}$ supplied to the soil are the same, $\mathrm{kg} \mathrm{N} \mathrm{ha}^{-1}$, in both cases for both manures and inorganic fertilizer.

The $\mathrm{N}$ equivalency value was estimated by the following equation according to Colwell (1994):

$$
\mathrm{N} \text { equivalency }(\%)=\frac{1 / b(y-a)}{\mathrm{N}} \times 100
$$

where $a$ is the regression intercept value), $b$ is the regression 4 coefficient, $y$ is the mean root yield recorded for the plots supplied with compost or FYM at a rate of 24 $\mathrm{m}^{3} \mathrm{ha}^{-1}$ and $\mathrm{N}$ is the rate of $\mathrm{N}$ application at $24 \mathrm{~m}^{3} \mathrm{ha}^{-1}$ of farmyard manure or compost.

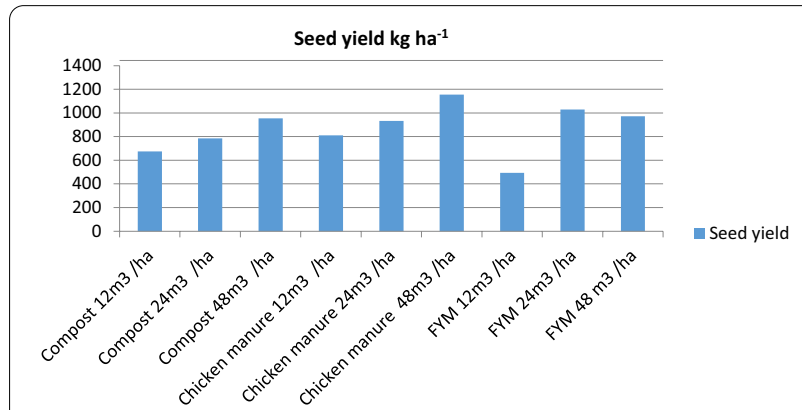

Fig. 2 Effect of manure types and rates on sesame yield

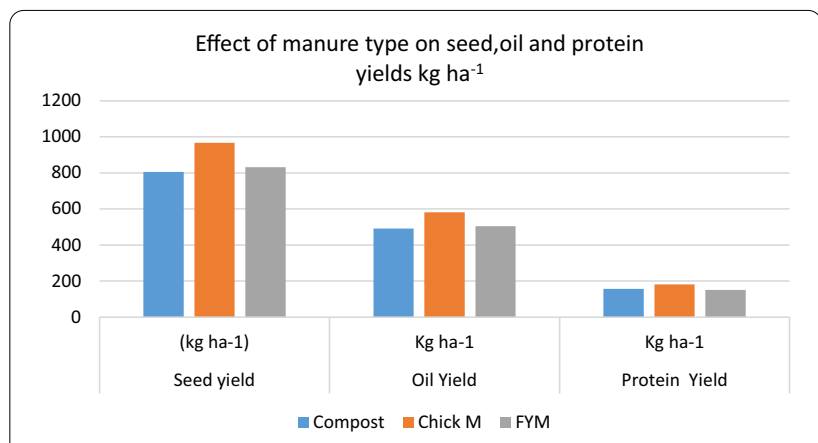

Fig. 3 Effect of manure type on seed, oil and protein yields $\mathrm{kg} \mathrm{ha}^{-1}$

\section{Statistical analysis}

The data were subjected to the proper statistical analysis using (MSTAT-C Software package 1988). Since the data in both seasons took similar trends, Bartlett's test was applied and the combined analysis of the data was done. For means comparison, least significant difference (LSD) at $5 \%$ level was applied.

\section{Results}

The chemical analysis of manure applied to the field trials is reported in Table 2. The manures contained more than 71.9, 73.1 and $91.4 \%$ dry solids for FYM, plant compost and chicken manure, respectively, indicating that they were generally similar. Therefore, the plant compost and chicken manure have comparable soil conditioning properties as the conventional bulky organic manure at equivalent rates of application to soil. Chicken manure contained $44 \%$ more $\mathrm{N}$ compared with the average content in FYM and fivefold increase compared to the plant compost (Table 3). Plant compost and FYM supplied similar amounts of total $\mathrm{P}$ in the dry solids. $\mathrm{K}$ excreted in the wastes of domestic livestock is largely retained in the bedding material that forms the main bulk matrix of FYM.

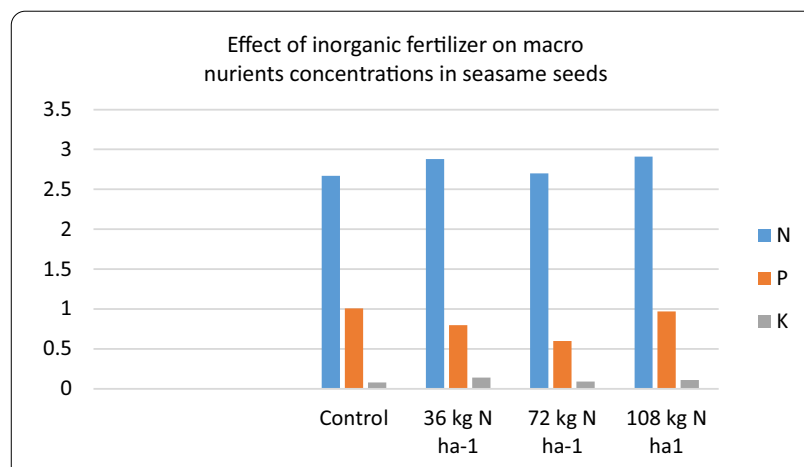

Fig. 4 Effect of inorganic fertilizer on macronutrients concentrations in sesame seeds \% 


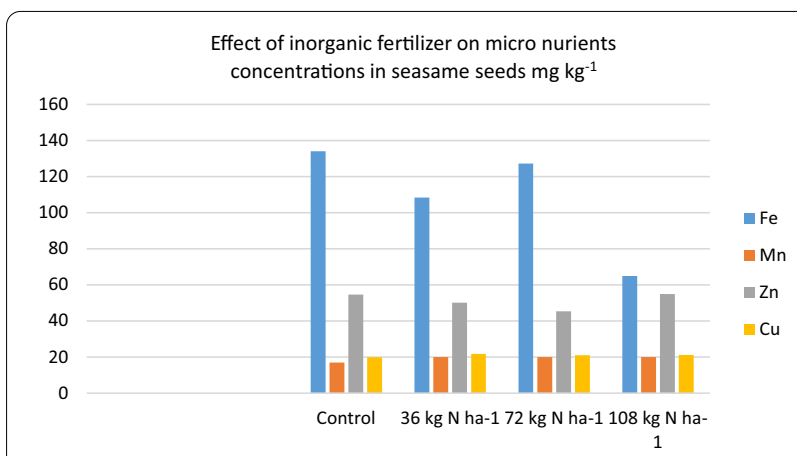

Fig. 5 Effect of inorganic fertilizer on micronutrients concentrations in sesame seeds

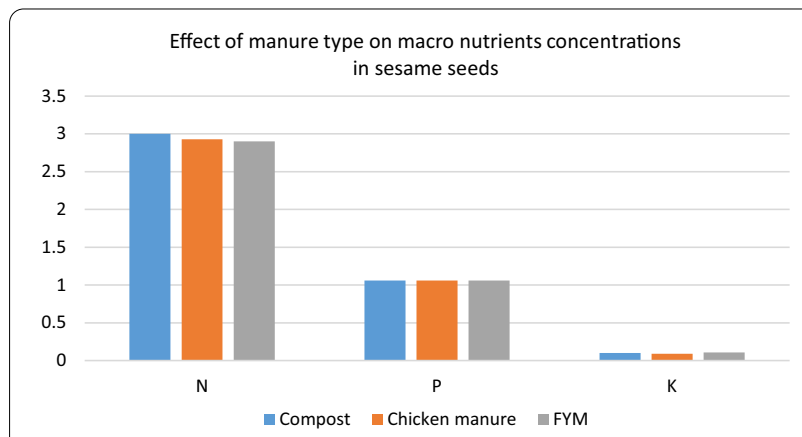

Fig. 6 Effect of manure type on macronutrients concentrations in sesame seeds

\section{Micronutrient addition in the different manures applied}

As expected, the concentrations of trace elements in the plant compost are larger than for FYM. Data presented in Table 4 and Fig. 1 show the four key micronutrients Fe, $\mathrm{Mn}, \mathrm{Zn}$ and $\mathrm{Cu}$ loading rates when applied by the different manures.

\section{Sesame yield and yield components}

Three-way ANOVA showed there were significant main effects of manure type and rate, and inorganic $\mathrm{N}$ fertilizer application on seed yield and yield components of sesame (Table 5). A significant interaction $(P=0.002)$ was also apparent between the type of manure and the rate of application.

Data presented in Table 6 show significant differences among different manure types on sesame number of branches plant ${ }^{-1}, 1000$-seed weight, seed yield ha ${ }^{-1}$, oil and protein yields $\mathrm{ha}^{-1}$. Application of chicken manure resulted in the highest significant increase in seed, protein and oil yields $\mathrm{ha}^{-1}$.

Data in Table 7 show gradual increases in sesame yield characters as $\mathrm{N}$ level increases over the control treatment. Seed, protein and oil yields reached their maximum values per hectare when sesame plants were fertilized with $108 \mathrm{~kg} \mathrm{~N} \mathrm{ha}^{-1}$ as compared with the other $\mathrm{N}$ levels or the control treatment. It is clear from the same table that application of moderate $\mathrm{N}$ levels $\left(72 \mathrm{~kg} \mathrm{~N} \mathrm{ha}^{-1}\right)$ alone resulted in reasonable yields but could not achieve the greatest seed, oil and protein yields reported by the higher $\mathrm{N}$ level $108 \mathrm{~kg} \mathrm{~N} \mathrm{ha}^{-1}$.

The measured yield characteristics of sesame are listed in Table 8, and the analysis of variance indicated highly significant effects of the interaction among experimental treatments on number of branches plant ${ }^{-1}, 1000$-seed weight $(\mathrm{g})$ seed, oil and protein yields $\left(\mathrm{kg} \mathrm{ha}^{-1}\right)$. Data presented in Table 8 show significant interaction effects among fertilizer treatments on No of branches plant ${ }^{-1}$, 1000 -seed weight and seed yield $\mathrm{kg} \mathrm{ha}^{-1}$. However, plant height and number of capsules plant ${ }^{-1}$ did not significantly affect. The highest seed yield $\mathrm{ha}^{-1}$ was achieved when chicken manure was applied at $48 \mathrm{~m}^{3} \mathrm{ha}^{-1}, 24$ $\mathrm{m}^{3}$ FYM combined with $72 \mathrm{~kg} \mathrm{~N}$ which mounted $15.9 \%$ and $9.7 \%$ increase over the recommended dose applied

Table 1 Physicochemical properties of soil samples from profile inspection pits at the field trial site

\begin{tabular}{|c|c|c|c|c|c|c|c|c|c|c|c|c|}
\hline \multirow[t]{2}{*}{ Depth (cm) } & \multirow[t]{2}{*}{$\begin{array}{l}\text { Gravels } \\
(\%>2 \mathrm{~mm})\end{array}$} & \multirow[t]{2}{*}{$\mathrm{CaCO}_{3}(\%)$} & \multirow[t]{2}{*}{ Gypsum (\%) } & \multirow[t]{2}{*}{$\mathrm{pH}$} & \multirow[t]{2}{*}{$\mathrm{EC}\left(\mathrm{dS} \mathrm{m}^{-1}\right)$} & \multicolumn{4}{|c|}{ Cation concentration $\left(\mathrm{me} \mathrm{I}^{-1}\right)$} & \multicolumn{3}{|c|}{$\begin{array}{l}\text { Anion concentration } \\
\left(\mathrm{me} \mathrm{I}^{-1}\right)\end{array}$} \\
\hline & & & & & & $\mathrm{Ca}^{2+}$ & $\mathrm{Mg}^{2+}$ & $\mathrm{Na}^{+}$ & $\mathrm{K}^{+}$ & $\mathrm{HCO}_{3}^{-}$ & $\mathrm{Cl}^{-}$ & $\mathrm{SO}_{4}{ }^{2-}$ \\
\hline $0-20$ & 25.6 & 5.6 & 0.23 & 8.81 & 6.3 & 30.2 & 11.1 & 25.1 & 1.2 & 2.4 & 29.3 & 35.9 \\
\hline $25-80$ & 28.8 & 18.0 & 0.09 & 8.66 & 7.1 & 35.6 & 12.1 & 30.4 & 1.7 & 3.6 & 28.1 & 48.1 \\
\hline $80-150$ & 19.2 & 19.2 & 0.14 & 8.83 & 7.5 & 40.1 & 9.3 & 33.6 & 1.3 & 3.8 & 35.1 & 45.4 \\
\hline
\end{tabular}

Table 2 Chemical analysis of bio-solids (units: ds, VS, N, P, K and Fe as \%; other elements as $\mathrm{mg} \mathrm{kg}^{-1}$ )

\begin{tabular}{|c|c|c|c|c|c|c|c|c|c|}
\hline Manure & ds & VS & $\mathrm{N}$ & $\mathbf{P}$ & K & $\mathrm{Fe}$ & $M n$ & $\mathrm{Zn}$ & $\mathrm{Cu}$ \\
\hline Plant compost & 73.1 & 59.8 & 0.37 & 0.72 & 0.14 & 0.78 & 283 & 40.3 & 16.0 \\
\hline Chicken manure & 91.4 & 66.0 & 1.73 & 1.23 & 0.14 & 0.84 & 440 & 52.4 & 16.0 \\
\hline FYM & 71.9 & 68.0 & 1.20 & 0.55 & 0.62 & 0.49 & 390 & 8.0 & 35 \\
\hline
\end{tabular}


Table 3 Nitrogen additions in bio-solids applied

\begin{tabular}{|c|c|c|c|c|}
\hline \multicolumn{2}{|c|}{ Manure applied } & \multirow{2}{*}{$\begin{array}{l}\text { Plant } \\
\text { compost kg N } \\
\text { ha }^{-1}\end{array}$} & \multirow{2}{*}{$\begin{array}{l}\text { Chicken } \\
\text { manure kg N } \\
\text { ha }^{-1}\end{array}$} & \multirow[t]{2}{*}{$\mathrm{FYM} \mathrm{kg} \mathrm{N} \mathrm{ha}^{-1}$} \\
\hline $\mathrm{tha}^{-1}$ & $\mathrm{~m}^{3} \mathrm{ha}^{-1}$ & & & \\
\hline 7.2 & 12 & 33.60 & 73.68 & 54.24 \\
\hline 14.4 & 24 & 66.96 & 147.36 & 108.48 \\
\hline 28.8 & 48 & 133.92 & 294.72 & 216.96 \\
\hline
\end{tabular}

(108 kg N), respectively (Fig. 2). Seed oil and protein contents \% were not significantly affected by treatments. The highest seed oil content $\%$ was determined when the plants were fertilized with the lower rate of $\mathrm{N}$ applied or the compost with or without the adjusted $\mathrm{N}$ rate $\left(72 \mathrm{~kg} \mathrm{~N} \mathrm{ha}^{-1}\right.$ ), while the highest protein\% was achieved by compost application at $12 \mathrm{~m}^{3}$ and chicken manure at $24 \mathrm{~m}^{3} \mathrm{ha}^{-1}$ alone (Fig. 3).

From the same table, it is clear that there were significant effects due to fertilizer treatments on oil and protein yields ha ${ }^{-1}$. Sesame fertilization with $48 \mathrm{~m}^{3}$ or farm yard manure at $24 \mathrm{~m}^{3}$ combined with $72 \mathrm{~kg} \mathrm{~N}^{-1}$ gave 15.1 and $6.8 \%$ increase over the recommended $\mathrm{N}$ rate $\left(108 \mathrm{~kg} \mathrm{~N} \mathrm{ha}^{-1}\right)$, respectively. Meanwhile, the same treatments produced 25 and $6.4 \%$ increase in protein yields over the recommended $\mathrm{N}$ rate applied. Such results could be attributed to the high $\mathrm{N}$ content in chicken manure and $\mathrm{K}$ in the farm yard manure.

\section{Correlation analysis}

Correlation analysis of the various yield characteristics showed that seed yield, capsule number and plant stature were raised significantly with increasing rate of applied mineral N (Table 9). Crop response to applied compost, chicken manure, FYM and inorganic $\mathrm{N}$ fertilizer followed a linear pattern and was effectively summarized by these simple regression models (Table 9).

\section{Nitrogen fertilizer equivalencies}

The $\mathrm{N}$ equivalency values which express the $\mathrm{N}$ fertilizer replacement value of the applied organic manures were estimated from the regression coefficients of the linear models and in relation to inorganic $\mathrm{N}$ fertilizer and are presented in Table 10. The $\mathrm{N}$ equivalence of chicken
Table 5 Results of ANOVA to assess the effects of manure type and rate, and $N$ fertilizer application on seed yield of sesame

\begin{tabular}{llcl}
\hline Source of variation & F-ratio & Probability & $\begin{array}{l}\text { Significance } \\
\text { level }\end{array}$ \\
\hline Blocks & 0.163 & 0.691 & $\mathrm{~ns}$ \\
Main effects & & & \\
Fertilizer (Fert.) & 49.5 & $<0.001$ & $* * *$ \\
Manure rate (Rate) & 45.1 & $<0.001$ & $* * *$ \\
Manure type (type) & 9.62 & 0.002 & $* *$ \\
Interactions & & & \\
Fert. $\times$ rate & 0.880 & 0.433 & $\mathrm{~ns}$ \\
Fert. $\times$ type & 3.26 & 0.063 & $\mathrm{~ns}$ \\
Rate $\times$ type & 6.44 & 0.002 & $* *$ \\
Fert. $\times$ rate $\times$ Type & 4.86 & 0.008 & $* *$ \\
\hline
\end{tabular}

manure was $50 \%$ of mineral $\mathrm{N}$, and the yield response to compost at equivalent rates of $\mathrm{N}$ addition was $30 \%$ of that obtained with inorganic $\mathrm{N}$ fertilizer.

\section{Total and available $\mathbf{N}$ supplied in organic manures}

On the basis of the sesame seed yield response to the applied organic manures and $\mathrm{N}$ fertilizer equivalency, the available $\mathrm{N}$ content of the applied compost, chicken manure and FYM is estimated to be: $1.4 \mathrm{~kg} \mathrm{~N} \mathrm{~m}^{-3}$ $\left(2.1 \mathrm{~kg} \mathrm{~N} \mathrm{t}^{-1} \mathrm{ds}\right), 3.1 \mathrm{~kg} \mathrm{~N} \mathrm{~m}^{-3}\left(5.1 \mathrm{~kg} \mathrm{~N} \mathrm{t}^{-1} \mathrm{ds}\right)$ and $1.7 \mathrm{~kg} \mathrm{~N} \mathrm{~m}^{-3}\left(1.7 \mathrm{~kg} \mathrm{~N} \mathrm{t}^{-1} \mathrm{ds}\right)$, respectively (Table 11$)$.

\section{Chemical composition of sesame seeds}

Data presented in Table 12 show that only P, Fe, Mn and $\mathrm{Cu}$ concentrations in sesame seed were significantly affected by the experimental treatments (Figs. 4, 5, 6). The results showed that copper and $\mathrm{P}$ concentrations in sesame seed were significantly affected by organic manures and improved the seed contents of these elements compared to inorganic fertilizer.

\section{Discussion}

Due to the bedding used in preparing FYM which is a relatively rich source of $\mathrm{K}$ compared with compost and contained more than four times the amount of $\mathrm{K}(0.62 \% \mathrm{ds})$ compared with chicken manure $(0.14 \% \mathrm{ds})$ or compost, compensation for the soil with this major plant nutrient

Table 4 micronutrients loading rates applied by the different manures

\begin{tabular}{|c|c|c|c|c|c|c|c|c|}
\hline \multirow[t]{2}{*}{ Manure } & \multicolumn{4}{|c|}{ Micronutrient addition $\mathrm{g} \mathrm{t}^{-1}$} & \multicolumn{4}{|c|}{ Micronutrient addition $\mathrm{g} \mathrm{m}^{-3}$} \\
\hline & $\mathrm{Fe}$ & $\mathrm{Mn}$ & $\mathrm{Zn}$ & $\mathrm{Cu}$ & $\mathrm{Fe}$ & $M n$ & $\mathrm{Zn}$ & $\mathrm{Cu}$ \\
\hline Plant compost & 570.0 & 206.9 & 29.5 & 11.7 & 416.0 & 144.8 & 20.6 & 8.4 \\
\hline Chicken manure & 767.0 & 402.2 & 47.9 & 14.6 & 461.0 & 241.3 & 28.7 & 8.8 \\
\hline FYM & 352.0 & 280.4 & 5.8 & 25.2 & 225.0 & 179.5 & 3.7 & 16.1 \\
\hline
\end{tabular}


Table 6 Effect of manure types on sesame yield components, oil and protein yields

\begin{tabular}{|c|c|c|c|c|c|c|c|c|c|}
\hline Manure type & $\begin{array}{l}\text { Plant } \\
\text { height } \\
\text { (cm) }\end{array}$ & $\begin{array}{l}\text { Branches } \\
\text { plant }^{-1}\end{array}$ & $\begin{array}{l}\text { Capsules } \\
\text { plant }^{-1}\end{array}$ & $\begin{array}{l}\text { 1000-seed } \\
\text { weight }(\mathrm{g})\end{array}$ & $\begin{array}{l}\text { Seed yield } \\
\left(\mathrm{kg} \mathrm{ha}^{-1}\right)\end{array}$ & $\begin{array}{l}\text { Seed oil } \\
\text { content }\end{array}$ & $\begin{array}{l}\text { Protein } \\
\text { content }\end{array}$ & $\begin{array}{l}\text { Oil yield kg } \\
\mathrm{ha}^{-1}\end{array}$ & $\begin{array}{l}\text { Protein } \\
\text { yield } \mathrm{kg} \\
\mathrm{ha}^{-1}\end{array}$ \\
\hline Compost & 115.8 & 6.2 & 86.4 & 3.1 & 804.6 & 61.1 & 19.6 & 490.8 & 157.4 \\
\hline $\begin{array}{l}\text { Chicken } \\
\text { manure }\end{array}$ & 125.7 & 7.7 & 114.7 & 3.1 & 966.8 & 59.9 & 18.8 & 580.9 & 181.4 \\
\hline FYM & 119.5 & 6.4 & 114.9 & 3.1 & 831.8 & 60.5 & 18.1 & 503.9 & 151.4 \\
\hline F probability & 0.41 & 0.01 & 0.24 & 0.02 & $<0.001$ & 0.409 & 0.443 & 0.226 & 0.305 \\
\hline LSD at 0.05 & ns & 5.35 & ns & ns & 425 & ns & ns & 34 & 21 \\
\hline CV (\%) & 10.8 & 27.8 & 64.8 & 10.8 & 33.4 & 10.8 & 3.4 & 8.8 & 6.4 \\
\hline
\end{tabular}

Table 7 Effect of $\mathrm{N}$ fertilizer rates on sesame yield components, oil and protein yields

\begin{tabular}{|c|c|c|c|c|c|c|c|c|c|}
\hline $\mathrm{N}$ fertilizer rates & $\begin{array}{l}\text { Plant } \\
\text { height } \\
\text { (cm) }\end{array}$ & $\begin{array}{l}\text { Branches } \\
\text { plant }^{-1}\end{array}$ & Capsules plant $^{-1}$ & $\begin{array}{l}\text { 1000-seed } \\
\text { weight }(\mathrm{g})\end{array}$ & $\begin{array}{l}\text { Seed yield } \\
\left(\mathrm{kg} \mathrm{ha}^{-1}\right)\end{array}$ & $\begin{array}{l}\text { Seed oil } \\
\text { content } \%\end{array}$ & $\begin{array}{l}\text { Protein } \\
\text { content\% }\end{array}$ & Oil yield kg ha ${ }^{-1}$ & $\begin{array}{l}\text { Protein } \\
\text { yield } \mathrm{kg} \\
\mathrm{ha}^{-1}\end{array}$ \\
\hline Control & 101.0 & 5.4 & 51.5 & 2.603 & 255.6 & 61.73 & 16.69 & 157.8 & 42.7 \\
\hline $36 \mathrm{~kg} \mathrm{~N} \mathrm{ha}^{-1}$ & 111.7 & 4.7 & 52.4 & 2.418 & 544.8 & 63.15 & 18.0 & 344.0 & 98.1 \\
\hline $72 \mathrm{~kg} \mathrm{~N} \mathrm{ha}^{-1}$ & 118.5 & 5.7 & 115.8 & 2.975 & 820.8 & 60.72 & 16.88 & 498.4 & 138.5 \\
\hline $108 \mathrm{~kg} \mathrm{~N} \mathrm{ha}^{-1}$ & 129.0 & 7.5 & 122.6 & 2.848 & 1194.0 & 62.11 & 18.19 & 741.6 & 217.2 \\
\hline F probability & 0.41 & 0.01 & 0.24 & 0.02 & $<0.001$ & 0.41 & 0.44 & $<0.001$ & 0.01 \\
\hline LSD at 0.05 & ns & 5.35 & ns & 0.509 & 425 & ns & ns & 54 & 36 \\
\hline CV (\%) & 10.8 & 27.8 & 64.8 & 10.8 & 33.4 & 10.8 & 3.4 & 12 & 22 \\
\hline
\end{tabular}

is recommended to maintain crop productivity through supplying FYM or inorganic $\mathrm{K}$ fertilizer in the crop rotation. The estimated $\mathrm{N}$ application from plant compost ranged between 33.6 and 133.9, farmyard manure 54.2 and 216.7 and chicken manure 73.7 and $294.7 \mathrm{~kg} \mathrm{~N}$ ha $^{-1}$ according to the rate of application. Similarly, chicken manure contained the greatest rates of Fe, Mn and $\mathrm{Zn}$ per ton or cubic meter. However, FYM contained the greatest $\mathrm{Cu}$ rates applied to the soil. This may be due to the high rates of $\mathrm{Cu}$ in animal diet. Abd El Lateef et al. (2018,2019b) reported substantial macro- and micronutrients applied to either cowpea or sugar peat through organic manures although the additions are rather small but on the long term will be significant under continues application and will be beneficial to the soil. Moreover, similar results were obtained by Sahu et al. (2017, 2018); they attributed the enhancing effect of manure to the gradual and slow release of nutrient to the soil as well as improving the soil physical properties to the benefit of the crop. The superiority of chicken manure than the other two sources was confirmed by Ogbonna and UmarShaba (2012). They showed that the application of poultry manure significantly promoted sesame growth and yield. Seed yield ha ${ }^{-1}$ was increased as manure rate was increased.
Regarding yield and yield components, it is clear that application of moderate $\mathrm{N}$ levels $\left(72 \mathrm{~kg} \mathrm{~N}^{-1}\right.$ ) alone resulted in reasonable yields but could not achieve the greatest seed, oil and protein yields reported by the higher $\mathrm{N}$ level $108 \mathrm{~kg} \mathrm{~N} \mathrm{ha}^{-1}$. The efficiency of $\mathrm{N}$ fertilizer on sesame yield characters was reported by Malik et al. (2003), Noorka et al. (2011), Umar et al. (2012), Elamin Ibrahim et al. (2014) and Elamin and Madhavi (2015); they revealed that the application of nitrogen at $80 \mathrm{~kg} \mathrm{ha}{ }^{-1}$ produced significantly higher seed yield of sesame due to enhanced value of yield attributes, viz. number of capsules plant ${ }^{-1}$, number of seeds capsule ${ }^{-1}$, seed yield (g plant ${ }^{-1}$ ) and harvest index as compared to other dose of nitrogen. It is emphasized, however, that the apparent increase in mean seed yield at the highest rate of chicken manure was explained by the inorganic $\mathrm{N}$ fertilizer treatment. Crop yield was not raised at the high rate of chicken manure without mineral $\mathrm{N}$ compared to the $24 \mathrm{~m}^{3} \mathrm{ha}^{-1}$. This behavior also explains the basis to the significant third-order interaction $(P=0.008)$ detected by ANOVA (Table 5).

The results of the integration of organic and inorganic fertilizer indicate that it could save better nutrient management in sesame with advantages of maintaining higher productivity and providing stability in crop 


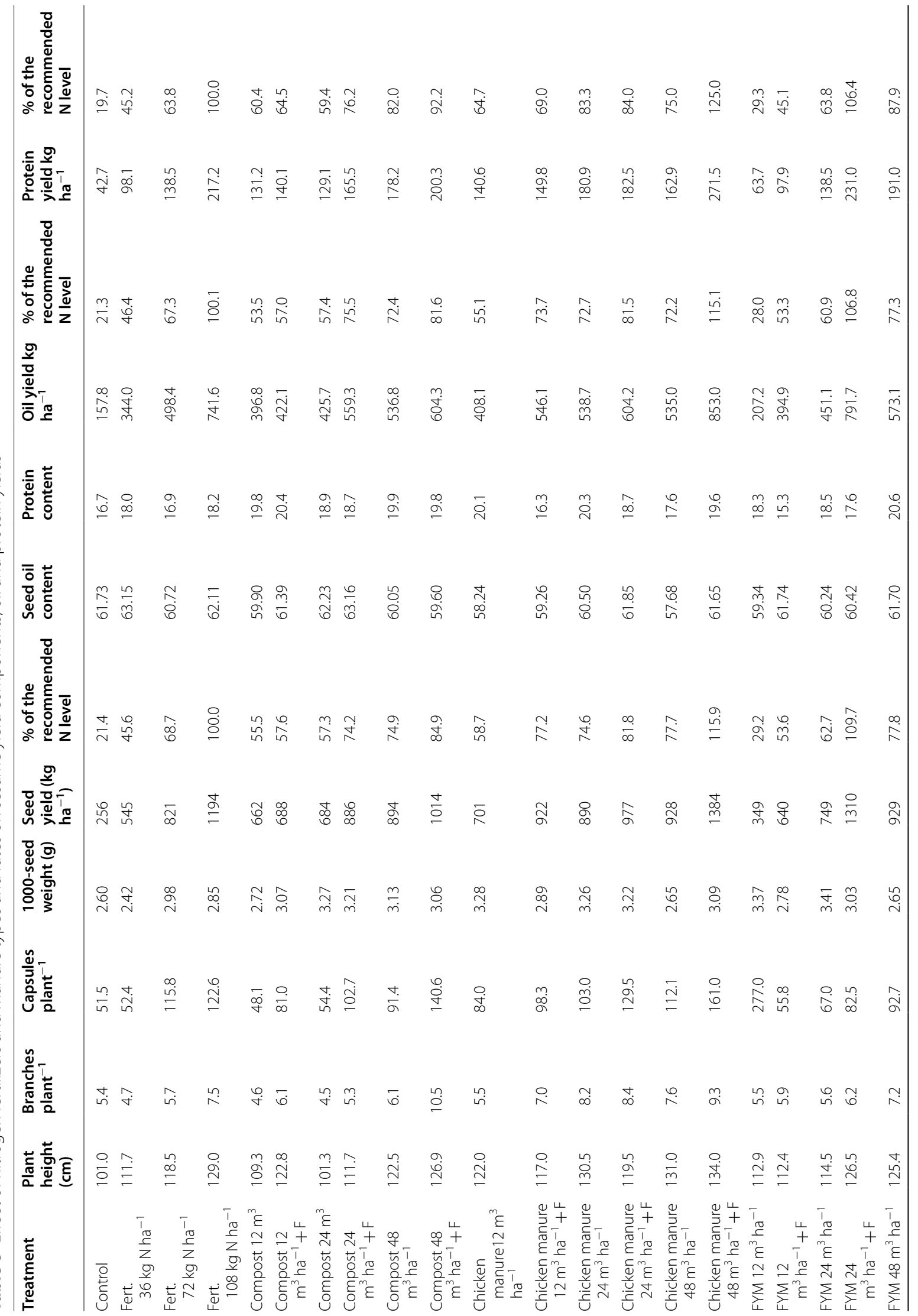




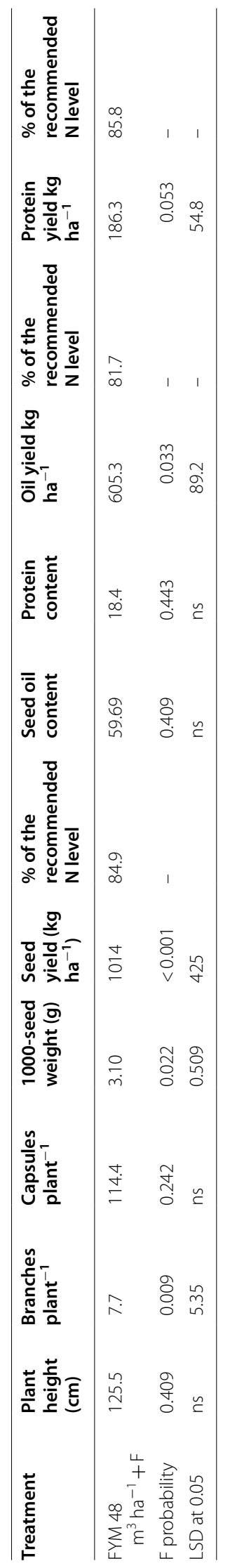


Table 9 Linear regression models of relationships $(y=a+b x)$ between sesame yield parameters and inorganic $\mathrm{N}$ fertilizer application

\begin{tabular}{|c|c|c|c|c|c|}
\hline Yield component & Constant (a) & $\begin{array}{l}\text { Regression coefficient } \\
\text { (b) }\end{array}$ & $r^{2}$ & Probability & $\begin{array}{l}\text { Significance } \\
\text { level }\end{array}$ \\
\hline Seed yield $\left(\mathrm{kg} \mathrm{ha}^{-1}\right)$ & 100.1 & 8.59 & 0.93 & $<0.001$ & $* * *$ \\
\hline 1000-seed weight (g) & No significant relationship & & & & \\
\hline Capsule no. plant ${ }^{-1}$ & 44.1 & 1.84 & 0.71 & 0.009 & $* *$ \\
\hline Branch no. plant ${ }^{-1}$ & No significant relationship & & & & \\
\hline Plant height (cm) & 101.4 & 0.605 & 0.89 & $<0.001$ & $* * *$ \\
\hline Seed oil content (\%) & No significant relationship & & & & \\
\hline
\end{tabular}

Application rates of inorganic $\mathrm{N}$ were: $0,36,72$ and $108 \mathrm{~kg} \mathrm{~N}$ ha $^{-1}$

Table 10 Nitrogen fertilizer equivalencies of different manure types estimated from linear regression coefficients of the relationships $(y=a+b x)$ between seed yield $\left(\mathrm{kg} \mathrm{ha}^{-1}\right)$ of sesame and the quantities of $\mathrm{N}$ applied $\left(\mathrm{kg} \mathrm{ha}^{-1}\right)$ in the manures

\begin{tabular}{lcccc}
\hline $\boldsymbol{N}$ source & Regression coefficient (b) & Probability & $\boldsymbol{r}^{\mathbf{2}}$ & $\begin{array}{l}\boldsymbol{N} \text { equivalence relative to } \\
\text { inorganic } \boldsymbol{N}(\%)\left(\boldsymbol{b}_{\text {orgN }} \div\right. \\
\left.\boldsymbol{b}_{\text {inorgN }} \times 100\right)\end{array}$ \\
\hline Compost & 2.61 & $0.003^{* *}$ & 0.80 & 30 \\
Chicken manure & 4.31 & $0.001^{* *}$ & 0.94 & 50 \\
FYM & 5.35 & $<0.001^{* * *}$ & 0.88 & 62 \\
Inorganic $N^{b}$ & 8.58 & $<0.001^{* * *}$ & 0.93 & \\
\hline
\end{tabular}

a $24 \mathrm{~m}^{3} \mathrm{ha}^{-1}$

${ }^{b}$ The maximum rate of application used in estimating the regression coefficient for compost, chicken manure and FYM

Table 11 Total and available N supplied in organic manures and FYM

\begin{tabular}{|c|c|c|c|c|}
\hline \multirow[t]{2}{*}{ N source } & \multicolumn{2}{|c|}{ Total N (ds) } & \multicolumn{2}{|c|}{ Available N (ds) } \\
\hline & $\mathrm{kg} \mathrm{t}^{-1}$ & $\mathrm{~kg} \mathrm{~m}^{-3}$ & $\mathrm{~kg} \mathrm{t}^{-1}$ & $\mathrm{~kg} \mathrm{~m}^{-3}$ \\
\hline Compost & 7.06 & 4.52 & 2.15 & 1.38 \\
\hline Chicken manure & 10.24 & 6.14 & 5.14 & 3.08 \\
\hline FYM & 2.66 & 2.79 & 1.66 & 1.74 \\
\hline
\end{tabular}

production, balanced proportion for sustainable production of sesame besides improving soil physical conditions (Teshome 2016; Sahu et al. 2017). Higher seed yield of sesame can be obtained by integrated use of fertilizer along with FYM Purushottam (2005). Chatterjee et al. (2017) and Sahu et al. (2017) came to similar conclusion.

Linear regression models formed on the basis of calculations of $\mathrm{N}$ fertilizer equivalency values for the manures showed that the crop response to applied compost, chicken manure, FYM and inorganic $\mathrm{N}$ fertilizer followed a linear pattern and were effectively summarized by these simple regression models. Binh and Lieu (2016) found that the correlation relationship between yield and yield attributes of sesame showed that seed yield strongly correlated with plant height $\left(r=0.93^{* * * *}\right)$, number of capsules plant $^{-1}\left(r=0.88^{* * * *}\right)$, number of seed $\left(0.86^{* * * *}\right)$, capsule length $\left(r=0.77^{* * * *}\right)$ capsule $\left(r=0.74^{* * *}\right)$, weight of 1000 seeds $\left(0.64^{* * * *}\right)$ and weight of seeds/five capsules $\left(0.61^{* * *}\right)$.

The $\mathrm{N}$ equivalence of chicken manure was $50 \%$ of mineral $\mathrm{N}$, and the yield response to compost at equivalent rates of $\mathrm{N}$ addition was $30 \%$ of that obtained with inorganic $\mathrm{N}$ fertilizer. The higher $\mathrm{N}$ equivalency (62\%) apparent for FYM compared with compost is probably explained by reasons other than its $\mathrm{N}$ content. For example, FYM contained more than four times the amount of $\mathrm{K}$ compared with compost which is frequently limiting to agricultural production in Egyptian soils (Table 1). In this respect, Abd El Lateef et al. (2019b) reported that the $\mathrm{N}$ equivalencies estimated for FYM were less consistent than for sewage sludge, reflecting the more variable chemical composition of FYM, and were usually similar to, or lower than, the sludge products. However, the $\mathrm{N}$ equivalency value calculated for FYM was apparently much larger than for manure with soybean. Farmyard manure increased seed yield of soybean by $60 \%$ compared with inorganic fertilizer supplied at equivalent rates of $\mathrm{N}$ addition.

The results of seed content of macro- and micronutrients showed that the organic materials significantly improved the seed status of these elements compared to inorganic fertilizer which was confirmed by Ibrahim 
Table 12 Chemical composition of sesame seed

\begin{tabular}{|c|c|c|c|c|c|c|c|c|c|c|c|}
\hline Treatment & $\mathrm{N}$ & $\mathbf{P}$ & $\mathrm{K}$ & $\mathrm{Fe}$ & $M n$ & $\mathrm{Zn}$ & $\mathrm{Cu}$ & $\mathrm{Ni}$ & Cd & $\mathrm{Pb}$ & Co \\
\hline Control & 2.67 & 1.01 & 0.08 & 134.1 & 17 & 54.7 & 19.9 & 13.2 & 1.1 & 6.6 & 1.4 \\
\hline Fert. $36 \mathrm{~kg} \mathrm{~N} \mathrm{ha}^{-1}$ & 2.88 & 0.80 & 0.14 & 108.4 & 20 & 50.2 & 21.7 & 15.1 & 1.1 & 5.3 & 1.3 \\
\hline Fert. $72 \mathrm{~kg} \mathrm{~N} \mathrm{ha}^{-1}$ & 2.70 & 0.60 & 0.09 & 127.2 & 20 & 45.3 & 21.0 & 11.5 & 1.0 & 7.1 & 1.4 \\
\hline Fert. $108 \mathrm{~kg} \mathrm{~N} \mathrm{ha}^{-1}$ & 2.91 & 0.97 & 0.11 & 65.0 & 20 & 55.0 & 21.2 & 11.7 & 0.9 & 6.9 & 2.0 \\
\hline Compost $12 \mathrm{~m}^{3}$ & 3.17 & 1.10 & 0.10 & 62.4 & 19 & 54.7 & 24.6 & 9.9 & 1.1 & 6.0 & 2.3 \\
\hline Compost $12 \mathrm{~m}^{3} \mathrm{ha}^{-1}+\mathrm{F}$ & 3.26 & 1.04 & 0.11 & 78.9 & 20 & 68.6 & 27.5 & 13.4 & 0.5 & 1.9 & 1.7 \\
\hline Compost $24 \mathrm{~m}^{3}$ & 3.02 & 1.04 & 0.12 & 101.4 & 22 & 66.6 & 25.7 & 15.7 & 1.1 & 5.5 & 3.1 \\
\hline Compost $24 \mathrm{~m}^{3} \mathrm{ha}^{-1}+\mathrm{F}$ & 2.99 & 1.12 & 0.11 & 69.7 & 18 & 46.1 & 24.7 & 13.2 & 1.0 & 4.0 & 1.7 \\
\hline Compost $48 \mathrm{~m}^{3} \mathrm{ha}^{-1}$ & 3.19 & 1.04 & 0.48 & 112.5 & 20 & 69.6 & 23.0 & 12.9 & 0.8 & 1.4 & 2.5 \\
\hline Compost $48 \mathrm{~m}^{3} \mathrm{ha}^{-1}+\mathrm{F}$ & 3.16 & 1.05 & 0.14 & 97.3 & 20 & 48.9 & 22.9 & 15.0 & 0.6 & 5.5 & 2.1 \\
\hline Chicken manure $12 \mathrm{~m}^{3} \mathrm{ha}^{-1}$ & 3.21 & 1.02 & 0.08 & 89.1 & 19 & 105.0 & 22.7 & 15.3 & 1.1 & 4.7 & 1.7 \\
\hline Chicken manure $12 \mathrm{~m}^{3} \mathrm{ha}^{-1}+\mathrm{F}$ & 2.60 & 1.14 & 0.12 & 70.9 & 18 & 54.2 & 22.8 & 10.2 & 1.0 & 3.5 & 2.0 \\
\hline Chicken manure $24 \mathrm{~m}^{3} \mathrm{ha}^{-1}$ & 3.25 & 1.08 & 0.11 & 89.1 & 20 & 68.3 & 22.0 & 12.6 & 1.0 & 1.7 & 1.7 \\
\hline Chicken manure $24 \mathrm{~m}^{3} \mathrm{ha}^{-1}+\mathrm{F}$ & 2.99 & 1.05 & 0.08 & 83.9 & 17 & 110.1 & 25.0 & 17.4 & 1.3 & 3.7 & 2.6 \\
\hline Chicken manure $48 \mathrm{~m}^{3} \mathrm{ha}^{-1}$ & 2.81 & 1.03 & 0.12 & 120.6 & 33 & 62.4 & 21.8 & 17.0 & 0.7 & 0.9 & 1.8 \\
\hline Chicken manure $48 \mathrm{~m}^{3} \mathrm{ha}^{-1}+\mathrm{F}$ & 3.14 & 1.02 & 0.07 & 73.3 & 16 & 42.7 & 23.7 & 14.4 & 0.6 & 5.7 & 2.2 \\
\hline FYM $12 \mathrm{~m}^{3} \mathrm{ha}^{-1}$ & 2.92 & 1.12 & 0.10 & 97.8 & 21 & 101.4 & 22.8 & 13.6 & 1.1 & 5.7 & 1.4 \\
\hline FYM $12 \mathrm{~m}^{3} \mathrm{ha}^{-1}+\mathrm{F}$ & 2.45 & 1.05 & 0.07 & 162.2 & 14 & 43.1 & 22.0 & 10.3 & 0.7 & 2.9 & 1.5 \\
\hline FYM $24 \mathrm{~m}^{3} \mathrm{ha}^{-1}$ & 2.96 & 1.00 & 0.10 & 79.9 & 20 & 45.0 & 21.5 & 10.7 & 1.2 & 1.6 & 2.5 \\
\hline FYM $24 \mathrm{~m}^{3} \mathrm{ha}^{-1}+\mathrm{F}$ & 2.82 & 1.05 & 0.12 & 105.0 & 19 & 52.3 & 22.2 & 14.4 & 1.1 & 3.2 & 2.0 \\
\hline FYM $48 \mathrm{~m}^{3} \mathrm{ha}^{-1}$ & 3.29 & 1.07 & 0.14 & 105.3 & 24 & 71.0 & 23.4 & 13.0 & 0.9 & 3.5 & 2.5 \\
\hline FYM $48 \mathrm{~m}^{3} \mathrm{ha}^{-1}+\mathrm{F}$ & 2.94 & 1.05 & 0.13 & 112.9 & 18 & 53.0 & 24.4 & 13.4 & 1.0 & 4.0 & 2.0 \\
\hline F probability & 0.22 & 0.02 & 0.37 & 0.05 & 0.03 & 0.29 & 0.01 & 0.97 & 0.65 & 0.27 & 0.44 \\
\hline LSD at 0.05 & ns & 0.41 & ns & 99.2 & 13 & ns & 5.5 & ns & ns & ns & ns \\
\hline
\end{tabular}

et al. (2014). Ewulo et al. (2007), Khaled et al. (2012) and Anguria et al. (2017) reported that combined application of organic manures enhanced uptake of N, P and K by plants and the level of each on its initial concentration in organic manure.

The results presented here for sesame are entirely consistent with $\mathrm{N}$ equivalency values. This implies that organic manures are relatively consistent materials for use as fertilizers and soil amendments in agriculture. Moreover, manures apply significant macro- and micronutrients with agronomic and economic value to such poor soils.

\section{Conclusion}

It could be concluded from this study that organic manures application could provide further evidence of the significant $\mathrm{N}$ fertilizer replacement value of organic manures on reclaimed desert soils. Chicken manure was $50 \%$ as effective as $\mathrm{N}$ source compared with inorganic $\mathrm{N}$ and compost was $30 \%$ as effective. The results presented for sesame are entirely consistent with $\mathrm{N}$ equivalency values. This implies that organic manures are relatively consistent materials for use as fertilizers and soil amendments in agriculture.

\section{Abbreviations}

FYM: Farm yard manure; DS: Dry solids; VS: Volatile solids; C.V\%: Coefficient of variation.

\section{Acknowledgements}

The authors would like to thank Dr. Ahmad Abou Stait the owner of the land for his facilitates during this work.

\section{Authors' contributions}

EMA and MSA conceived and designed the experiments, MSA and AW performed the experiments and analyzed the data, and EMA, MSA and AW wrote the paper and reviewed the manuscript. All authors read and approved the final manuscript.

\section{Funding}

The work was self-funded by the authors.

Availability of data and materials

The datasets supporting the results are included within the article.

\section{Declarations}

Ethics approval and consent to participate Not applicable. 


\section{Consent for publication}

Not applicable.

\section{Competing interests}

The authors declare that they have no competing interests.

\section{Author details}

${ }^{1}$ Agricultural Division, Field Crops Research Department, National Research Centre, 33 El-Behooth St., Giza, Egypt. ²Plant Production Department, Arid Lands Cultivation Research Institute at (SRTA-City), New Borg El-Arab, Alexandria 21934, Egypt.

Received: 18 January 2021 Accepted: 25 April 2021

Published online: 10 May 2021

\section{References}

Abd El-Lateef EM, Abd El-Salam MS, Elewa TA, Wali AM (2018) Effect of organic manures and adjusted $\mathrm{N}$ application on cowpea (Vigna unguiculata L. Walp) yield, quality and nutrient removal in sandy soil. Middle East J Appl Sci 8(1):7-18

Abd El-Lateef EM, Abd El-Salam MS, Elewa TA, Farrag AA (2019a) Effect of organic manure and nitrogen level on sugar beet (Beta vulgaris var. saccharifera L.) yield and root nitrate content. Am-Euras J Agron 12(1):1-5. https://doi.org/10.5829/idosi.aeja.2019.01.05

Abd El-Lateef EM, Abd El-Salam MS, Yassen AA, Salem AKM, Mekki BB, Yousef ARM (2019b) Statistical modelling of nitrogen fertilizer value of different manure types in crop rotation. Int J Sustain Agric 7(1-3):1-9. https://doi. org/10.5829/idosi.ijsa.2019.01.09

Abdel-Sabour MF, El-Seoud MAA (1996) Effect of organic waste compost addition on sesame growth, yield and chemical composition. Agric Ecosyst Environ 60(2-3):157-164. https://doi.org/10.1016/S0167-8809(96)01083-3

Anguria P, Cheminingwa GN, Onwonga RN, Ugen MA (2017) Effect of organic manures on nutrient uptake and seed quality of sesame. J Agric Sci. https://doi.org/10.5539/jas.v9n7p135

Anyanga WO, Obong YY (2001) Sesame (Sesamum indicum L.) In: Mukiibi JK (ed) Agriculture in Uganda crops 11: 97-102 https://doi.org/10.5897/ JPBCS2016.0586

AOAC (2005) Association of official agriculture chemist. Official method of analysis, 16th edn, Washington, DC, pp 5-29. http://sutlib2.sut.ac.th/sut_ contents/H125800.pdf

Ashri A (1989) Sesame breeding objectives and approaches. In: Omran A (ed) Oil crops: sunflower, linseed and sesame, IDRCMR205E, IDRC, Ottawa. https://doi.org/10.5897/JPBCS2016.0586

Bedigian D (2003) Evolution of sesame (revisited): domestication, diversity and prospects. Genet Resour Crop Evol 50:779-787. https://doi.org/10. 1023/A:1025029903549

Binh NT, Lieu NT (2016) Response of sesame (Sesamum indicum L.) to Inorganic nitrogen application rates and organic fertilizers on grey soil in Hochiminh city Vietnam. Asian Res J Agric 2(4):1-9. https://doi.org/10. 9734/ARJA/2016/30745

Chapman HD, Pratt PF (1978) Methods of analysis for soils, plants and water, Univ California. Div Agric Sci 4030:12-19

Chatterjee N, Ghosh GK, Ghosh GK (2017) Effect of integrated nutrient management on yield, growth attributes and microbial population of sesame (Sesamum indicum). Int J Curr Microbiol Appl Sci 6(7):462-468. https:// doi.org/10.20546/ijcmas.2017.607.055

Colwell JK (1994) Estimating fertilizer requirements: a quantitative approach, CAB International, Wallingford UK. https://www.scirp.org/(S(351jmbntvn sjt1 aadkposzje))/reference/ReferencesPapers.aspx?ReferencelD $=440840$

Cooke GW (1982) Fertilizing for maximum yield, Granada Publishing, 3rd edn, London. https://doi.org/10.1017/S0014479700012837

Craswell ET, Lefroy RDB (2001) The role and function of organic matter in tropical soils. Nutr Cycl Agroecosyst 61:7-18. https://doi.org/10.1023/A: 1013656024633

Elamin AY, Madhavi K (2015) Residual effect of integrated nutrient management on growth and yield parameters of rabi chickpea (Cicer arietinum L.) under cropping system. Am J Sci Ind Res 6(5):103-109. https://doi.org/10. 5251/ajsir.2015.6.5.103.109

Wikipedia Encyclopedia (2009) Sesame Output. http://www.en.wikipedia.org/ wiki/sesame. Accessed 30 Jan 2010

Ewulo BS, Hassan KO, Ojeniyi SO (2007) Comparative effect of cow dung manure on soil and leaf nutrient and yield of pepper. Int J Agric Res 2:1043-1048. https://doi.org/10.3923/ijar.2007.1043.1048

Haruna IM, Abimiku MS (2012) Yield of sesame (Sesamum indicum L.) as influenced by organic fertilizers in the Southern Guinea Savanna of Nigeria. Sustain Agric Res 1(1):66-69. https://doi.org/10.5539/sar.v1n1p66

Ibrahim M, Hussain M, Khan A, Malik MFA (2014) Effect of nitrogen and phosphorus on yield and yield components of sesame (Sesamum indicum L.). Int J Sci Basic Appl Res (IJSBAR) 18(1):95-101. https://doi.org/10.13140/2. 1.4456 .8965

Jackson ML (1967) Soil chemical analysis. Prentice Hall of India, New Delhi, pp 251-280

Khaled AS, Mona G, El-Kader A, Zeinab MK (2012) Effect of soil amendments on soil fertility and sesame crop productivity under newly reclaimed soil conditions. J Appl Sci Res 8(3):1568-1575

Malik MA, Saleem MF, Ahmed S (2003) Influence of different nitrogen level on productivity of sesame (Sesamum indicum L.) under varying planting patterns. Int J Agric Biol 5(4):490-492

Mbagwu JSC, Ekwealor GC (1990) Agronomic potential of brewers spent grain. Biol Wastes 34:335-347. https://doi.org/10.1016/0269-7483(90)90034-P

Morris JB (2002) Food, industrial, nutraceutical, and pharmaceutical uses of sesame genetic resources. In: Janick J, Whipkey A (eds) Trends in new crops and new uses. ASHS Press, Arlington, VA, pp 153-156

MSTAT-C (1988) MSTAT-C, a microcomputer program for the design, arrangement and analysis of agronomic research. Michigan State University East Lansing. https://www.canr.msu.edu/afre/projects/microcomputer_stati stical_package_mstat._1983_1985

Murphy BW (2015) Impact of soil organic matter on soil properties-a review with emphasis on Australian soils. Soil Res 53(6):605-635. https://doi.org/ $10.1071 /$ SR 14246

NCRI (2005) Technology of Beniseed (Sesame) Production, 3rd ed. NCRI Printing Unit, p 45

Noorka IR, Hafiz SI, El-Bramawy MAS (2011) Response of sesame to population densities and nitrogen fertilization on newly reclaimed sandy soils. Pak J Bot 43(4):1953-1958

Ogbonna PE, Umar-Shaba YG (2012) Influence of poultry manure application on growth and yield performance of accessions of sesame (Sesamum indicum L.) in a derived savanna transition zone of South eastern Nigeria. Afr J Agric Res 7(30):4223-4235. https://doi.org/10.5897/AJAR11.2069

Purushottam G (2005) Integrated nutrient management in sesame (Sesamum indicum L.) and its residual effect on succeeding chickpea (Cicer arietinum L.). M Sc Thesis, UAS, Dharwad, Karnataka, pp 102. URI http://krishikosh. egranth.ac.in/handle/1/80490

Sahu G, Chatterjee N, Bera M, Ghosh GK, Mondal S, Biswas PK, Kundu MC (2017) Integrated nutrient management in sesame (Sesamum indicum) in red and lateritic soils of West Bengal. Int J Plant Anim Environ Sci. https:// doi.org/10.21276/ljpaes https://doi.org/10.21276/ijpaes

Singh H, Singh RP, Meena BP, Lal B, Dotaniya ML, Shirale AO, Kumar K (2018) Effect of integrated nutrient management (INM) modules on late sown Indian mustard [B. juncea (L.) Cernj. \& Cosson] and soil properties. J Cereals Oilseeds 9(4):37-44. https://doi.org/10.5897/JCO2016.0155

Teshome T (2016) Effects of Nitrogen, phosphorous (inorganic fertilizers) and Farm Yard Manure on growth, yield, yield components and oil contents of Sesame (Sesamum indicum L) at Assosa district, Beneshangul Gumuze Region Ethiopia. Nat Sci 14(12):10-28. https://doi.org/10.7537/marsn sj141216.04

Umar UA, Mahmud M, Abubakar IU, Babaji BA, Idris UD (2012) Performance of sesame (Sesamum indicum L.) varieties as influenced by nitrogen fertilizer level and intra row spacings. Pac J Sci Technol 13(2):364-369

\section{Publisher's Note}

Springer Nature remains neutral with regard to jurisdictional claims in published maps and institutional affiliations. 